\title{
Completed Representation of Electronic School Book (ESB) on Physics Subjects at Senior High School
}

\author{
$1^{\text {st }}$ Irfan Yusuf \\ i.yusuf@unipa.ac.id
}

\author{
$2^{\text {nd }}$ Sri Widyaningsih
}

s.widyaningsih@unipa.ac.id $3^{\text {rd }}$ Imelda Mallipa

i.mallipa@unipa.ac.id

\begin{abstract}
This study aims to describe the completeness of the Electronic School Book (ESB) on physics subjects at high school. This research was descriptive qualitative research. This research was conducted by selecting 21 ESB books available on the website of the central office of the Ministry of Education and Culturein Indonesia which consist of 7 books for class X, XI, and XII. The research was conducted by analyzing the aspects of physics book completeness including achievement indicator (I), content (C), evaluation $(E)$, view $(V)$, dan language $(L)$. Based on the results of Rasch Model analysis, it is found that the complete book of class X physics is the BX04 book and the less complete is BX02 and BX03, while the other book is quite complete. Completeness rarely possessed by physics book class $X$ is on the aspect of the systematic presentation of material following the curriculum 2013 (C4), conformity with learning objectives (C3), and clarity of learning objectives (I1). The complete book of class XI physics is BXI02, and the less complete are BXI03 and BXI06. Completeness is lacking on the aspect of initial/pretest competence (E1), experimental physics activity (C5), and systematic presentation of material following the curriculum 2013 (C4). The complete book of class XII physics is BXII02, BXII03, and BXII05 while the less complete are books BXII04 and BXII07. Completeness is lacking in class XII physics book that is on aspects of early competence presence/pretest (E1), compliance with the learning objectives (C3), the systematic presentation of the material according to curriculum 2013 (C4), and the clarity of learning objectives (I1). Overall, it can be concluded that most available physics ESB books have been good but not following the systematic presentation of the material in the 2013 curriculum and have not had a clear learning objective so that there is a mismatch of material with the purpose of learning.
\end{abstract}

\section{Keywords-ESB; book completion; and Curriculum}

\section{INTRODUCTION}

Materials and teaching materials are an essential part in supporting the implementation of learning in schools. Teachers can be more easily in carrying out learning activities through the availability of teaching materials, as well as with learners will be easier to learn the material through the available teaching materials [1,2]. One of the forms of teaching materials is textbook. Textbooks are the primary learning resources for achieving core competencies. The content of textbooks is a more detailed description of the subject matter of the educational curriculum. Components of the curriculum such as core competencies, basic competencies, competency achievement indicators, learning objectives, and subject matter must be visible in the textbook.

Completeness of textbooks is determined by various components such as the suitability of the textbook content with the curriculum, the correctness of the concepts contained therein, as well as the display and presentation of the textbook [3]. Textbooks are a very useful resource for learners and teachers in supporting teaching and learning activities at school [4]. Lesson textbooks used as school reference consists of two types: Electronic School Book (ESB) and School Book Print (non-ESB). The learners can improve their insights by studying the material presented in the electronic school book. ESB has several advantages compared to other types of educational media that can be used efficiently to study anywhere and anytime, can increase the motivation and liveliness of learners, thus improving their academic achievement [5,6]. The use of ESB books is also very effective to use because it does not have to be printed to save costs [7].

ESB is a lesson textbook issued by the government through a feasibility test by BSNP in Indonesia, while non-ESB textbooks are textbooks published by various book publishers. The high cost of school books motivates ESB's program as one of the supporting educational facilities. Then the Minister of Education and Culture in Indonesia seeks the availability of cheap and quality books for learners with electronic school book programs. This policy is based on Permendiknas number 2 the year 2008 about Book.

The diversity of lesson textbooks, great opportunities for the emergence of differences in the arrangement that affects the understanding of learners. As a result, it is feared that many textbook lessons or even not worthy to be used as a learning guide, especially for learners. Educators need to select and 
evaluate the book that will serve as a reference in learning [8]. Based on these problems, the research is conducted in the form of ESB for completeness analysis used in Senior High School.

\section{EXPERIMENTAL METHOD}

This research was descriptive qualitative research. This research was conducted by selecting 21 ESB books available on the website at the center of the education and culture ministry in Indonesia, each consists of 7 books for class X, XI, and XII. The research was conducted by analyzing the aspects of physics book including achievement indicators (I), content (C), evaluation (E), view (V), and language (L). The instrument used is the observation sheet of the book completeness adopted according to Science Textbook Rating System (STRS) $[9,10]$ and the standard of textbook review as Government Regulation of the Republic of Indonesia number 32 of 2013 on the national standard of education: content, language, presentation, and textbook content are reviewed and assessed by BSNP or team established by the Minister and subsequently stipulated by Minister Regulation. Table 1 shows the ESB study textbook criteria.

TABLE 1. Aspects of assessment on ESB textbooks

\begin{tabular}{|c|c|c|c|}
\hline No & $\begin{array}{l}\text { Aspects of } \\
\text { assessment }\end{array}$ & Statement & Code \\
\hline \multirow{2}{*}{1} & \multirow{2}{*}{$\begin{array}{l}\text { Indicator of } \\
\text { achievement }\end{array}$} & $\begin{array}{c}\text { Clarity of learning } \\
\text { objectives }\end{array}$ & I1 \\
\hline & & $\begin{array}{l}\text { Clarity of perseption } \\
\text { and motivation }\end{array}$ & $\mathrm{I} 2$ \\
\hline \multirow{8}{*}{2} & \multirow{8}{*}{$\begin{array}{l}\text { Material } \\
\text { Content }\end{array}$} & $\begin{array}{c}\text { There is a concept } \\
\text { map or mind mapping }\end{array}$ & $\mathrm{C} 1$ \\
\hline & & $\begin{array}{l}\text { The truth of the } \\
\text { subject matter }\end{array}$ & $\mathrm{C} 2$ \\
\hline & & $\begin{array}{c}\text { Conformity of } \\
\text { material with learning } \\
\text { objectives }\end{array}$ & $\mathrm{C} 3$ \\
\hline & & $\begin{array}{c}\text { The systematical } \\
\text { presentation of the } \\
\text { material by the } 2013 \\
\text { curriculum }\end{array}$ & $\mathrm{C} 4$ \\
\hline & & $\begin{array}{c}\text { Equipped with } \\
\text { experimental physics } \\
\text { activities }\end{array}$ & $\mathrm{C} 5$ \\
\hline & & $\begin{array}{c}\text { There is a material } \\
\text { summary }\end{array}$ & C6 \\
\hline & & $\begin{array}{c}\text { There is a glossary } \\
\text { (the meaning of the } \\
\text { term) }\end{array}$ & $\mathrm{C} 7$ \\
\hline & & $\begin{array}{c}\text { There is a } \\
\text { bibliography }\end{array}$ & $\mathrm{C} 8$ \\
\hline \multirow[t]{2}{*}{3} & \multirow[t]{2}{*}{ Evaluation } & $\begin{array}{l}\text { There is an initial } \\
\text { competence test } \\
\text { (pretest) }\end{array}$ & E1 \\
\hline & & $\begin{array}{l}\text { Examples of problems } \\
\text { in accordance with the }\end{array}$ & E2 \\
\hline
\end{tabular}

\begin{tabular}{|c|c|c|c|}
\hline & & $\begin{array}{c}\text { material } \\
\text { Exercise questions } \\
\text { according to the } \\
\text { material } \\
\text { Exercise given } \\
\text { problem available } \\
\text { answer key }\end{array}$ & E3 \\
\hline \multirow{4}{*}{4} & \multirow{4}{*}{ Display } & $\begin{array}{c}\text { Images and } \\
\text { illustrations } \\
\text { correspond to the } \\
\text { material }\end{array}$ & V1 \\
\hline & & Interesting view & $\mathrm{V} 2$ \\
\hline & & $\begin{array}{c}\text { Clarity of symbols and } \\
\text { equations }\end{array}$ & V3 \\
\hline & & $\begin{array}{c}\text { The writing is easy to } \\
\text { read }\end{array}$ & V4 \\
\hline \multirow{3}{*}{5} & \multirow{3}{*}{ Language } & $\begin{array}{l}\text { Language usage is } \\
\text { reviewed from the } \\
\text { EYD rule }\end{array}$ & L1 \\
\hline & & $\begin{array}{l}\text { The language used is } \\
\text { communicative }\end{array}$ & L2 \\
\hline & & $\begin{array}{l}\text { The terms used are } \\
\text { precise and easy to } \\
\text { understand }\end{array}$ & L3 \\
\hline
\end{tabular}

Data analysis techniques used Rasch modeling techniques. Rasch modeling is an advanced analytical technique that can describe various characteristics that are assessed on the principle of probability [11].

\section{RESULT AND DISCUSSION}

Assessment of the completeness of the textbook is done in depth by looking at the entire contents of the ESB book. Assessment is conducted on five assessment indicators, namely achievement indicator, content, evaluation, display, and language. The results of the Rasch Model analysis of the $\mathrm{X}$ class book are shown in Figure 1. 


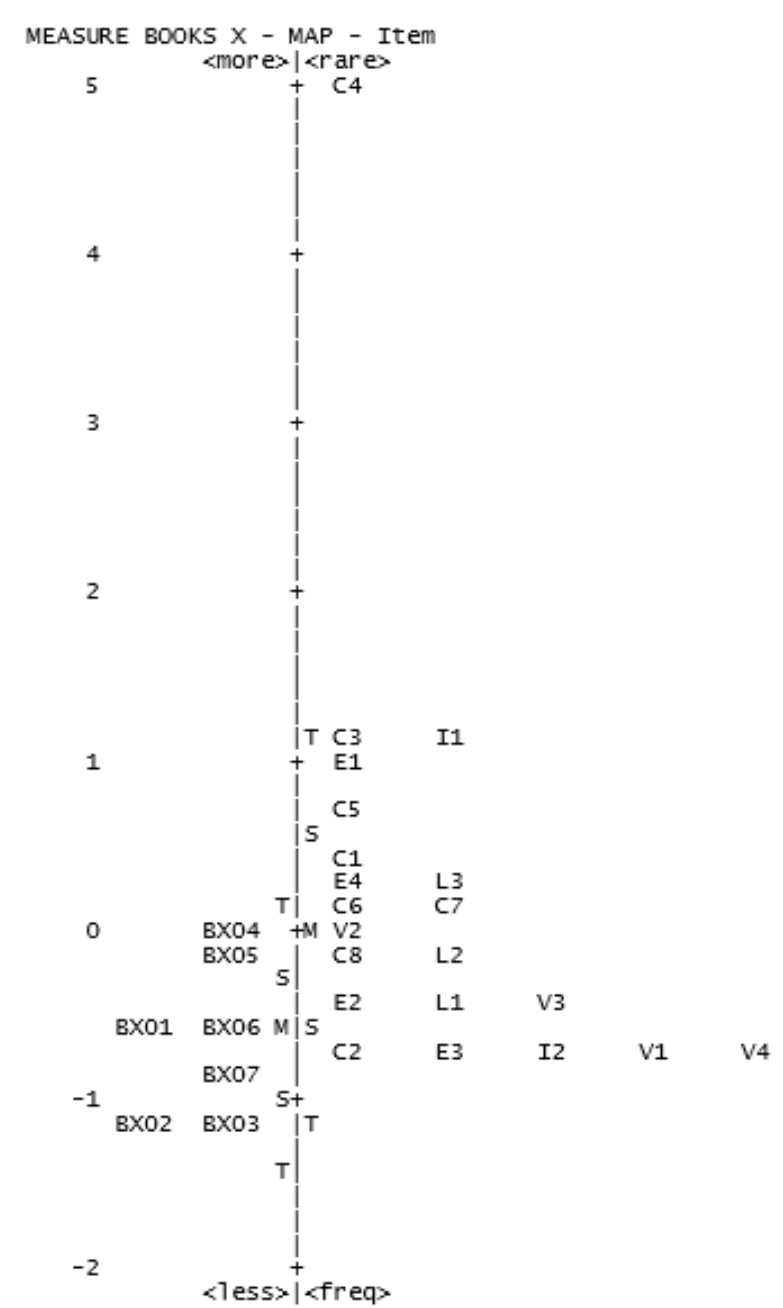

FIGURE 1.The result of physics book analysis in class $X$

The results of Rasch Model analysis based on Figure 1 show that the complete book of physics ESB class X is BX04 and the less complete is BX02 and $\mathrm{BX} 03$, while the other book is quite complete. The completeness that is rarely owned by physics book ESB class $X$ is on aspects of systematic presentation of materials following the curriculum in 2013 (C4). The available ESB have not been adapted to the 2013 curriculum as most available ESB books are compiled before the enactment of the 2013 curriculum in schools so that the composition of the material needs to be reviewed if it is to be used. Most ESB also lack the systematic uniformity of writing, both regarding the placement of material parts and the learning activities required in each ESB. The material systematics are essential to provide gradual understanding to learners [12]. Other deficiencies are in the aspects of conformity with learning objectives (C3), and clarity of learning objectives (I1). Some ESBs analyzed have no learning objectives. Figure 2 shows an example of providing learning objectives in an ESB.

\section{Tujuan Pembelajaran}

- Anda dapat mengukuir besaran panjang, massa, dan wonktu, serta dapat mi
penjumlahan vektor.

FIGURE 2. The learning objectives contained in the ESB

The purpose of learning is very important to be included in the book ESB as a reference for learners in learning material. Learning objectives are also a reference in the preparation of learning evaluation questions. The completeness of electronic books such as the purpose of learning is very important to support the achievement of competence to be achieved [13]. Completeness of other less is in the aspect of the existence of initial/pretest competence (E1) Figure 3 shows examples of pretest in the book.

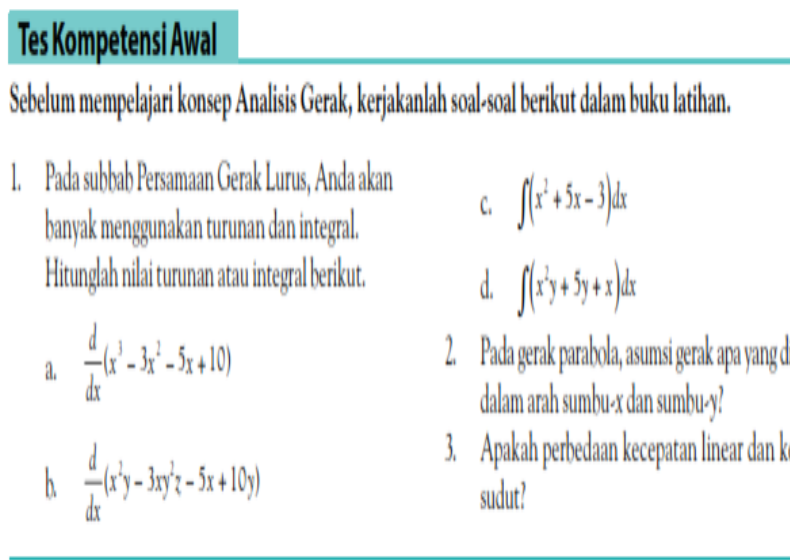

FIGURE 3.Examples of ESB that have pretest question

Giving pretest is very important to know the initial ability possessed by learners before starting lesson so that can be done next learning. School textbooks should be able to develop learners' skills in understanding the material [14]. Another aspect that is lacked in the ESB is on the aspect of C5 that is not yet equipped with experimental activities physics. Figure 4 shows an example of a physics experiment activity in an ESB. 


\section{Aktivitas Fisika 2.1}

\section{Tujuan Percobaan}

Gaya Gesek

Membedakan antara gaya gesek statis dan gaya gesek kinetik

Alat-Alat Percobaan

1. Balok kayu

2. Katrol

3. Tali

4. Neraca pegas/Dinamometer

Langkah-Langkah Percobaan

1. Susunlah alat-alat percobaan seperti pada gambar.

2. Tarik balok sehingga balok tepat akan bergerak.

3. Catatlah skala yang ditunjukkan neraca pegas.

4. Tarik kembali balok tersebut dengan gaya tarik yang lebih be gaya tarik pertama sehingga balok bergerak.

5. Pada saat balok bergerak, catatlah kembali skala yang ditunjı pegas.

6. Apa yang dapat Anda simpulkan?

FIGURE 4.Inclusion in experimental physics activities in ESB

Physical experimental activities can be simple experiments performed directly by learners by the study of the material being studied. Physical experiments are essential to provide conceptual understanding to learners $[15,16]$. The ESB should have a direct experimental study of the underlying concepts of physics presented to provide an understanding of experimental skills for the learners [17].

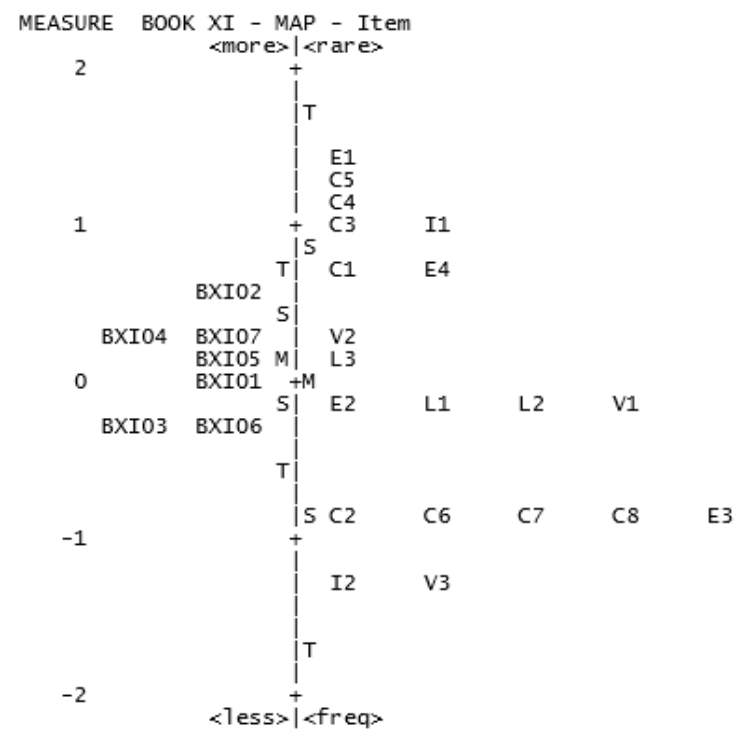

FIGURE 5.Analysis Results on Physics Book Class XI

Figure 5 shows that the complete book of physics class XI is BXI02 and the less complete are BXI03 and BXI06. Completeness is lacking on the aspect of the existence of initial/pretest competence (E1) as in the result of ESB class X book analysis. Other lesser aspects are the experimental activities of physics

(C5), systematic aspects of presentation of material following the curriculum 2013 (C4), learning objectives (C3), and clarity of learning objectives (I1). What another aspect lacks in the ESB is on the aspect of concept map or mind mapping (C1). Figure 6 shows an example of a concept map inclusion in an ESB.

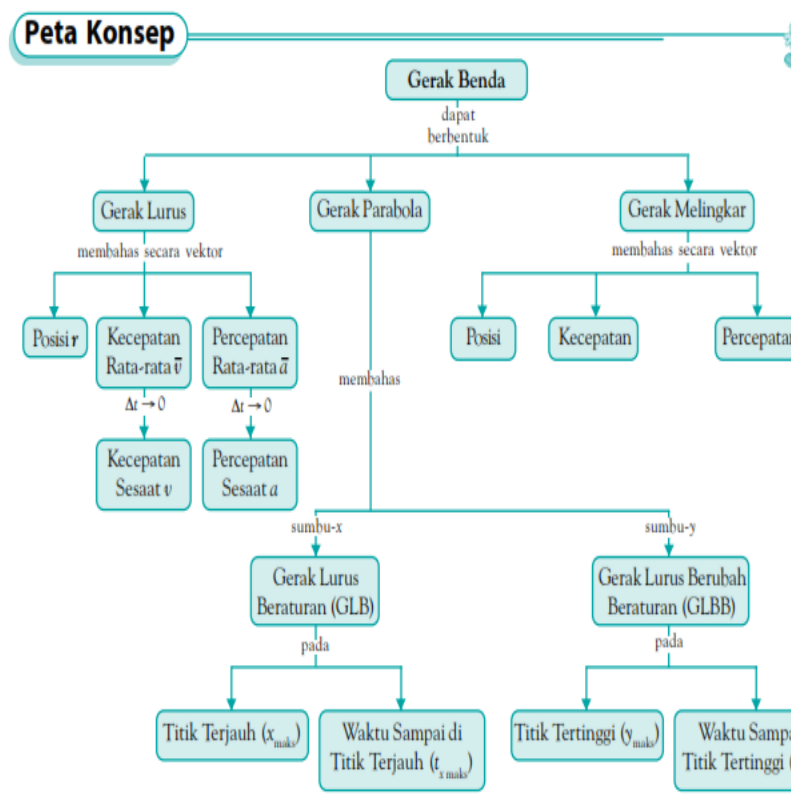

FIGURE 6.Concept maps contained in ESB

Giving concept maps to ESBs can be a reference for learners in understanding the material because all material concepts are directly and systematically illustrated [18]. Concept maps can enhance learners' comprehension comprehensively on learning subject matter [19]. Another aspect that is rarely possessed by the book is on the aspect of the exercise given questions available key answer (E4). Figure 7 shows an example of an ESB that has an answer key listed on the final page of an ESB book.

\section{Kunci Jawaban}

$$
\begin{aligned}
& \text { Bab } 1 \text { Analisis Gerak } \\
& \text { Tes Kompetensi Awal } \\
& \begin{aligned}
\text { 1. a. } 3 x^{2}-6 x-5 \\
\text { b. } 2 x y-6 x y z-5 \\
\text { c. } \frac{1}{3} x^{3}+\frac{5}{2} x^{2}-3 x+C \\
\text { d. } \frac{1}{3} x^{3} y+5 x y+\frac{1}{2} x^{2}+C
\end{aligned}
\end{aligned}
$$

3. Kecepatan linear memiliki perpindahan linear, sedangkan kecepatan sudut memiliki perpindahan radial.

$-. .2-1 . . .$.

FIGURE 7.The inclusion of answer keys in ESB

Giving an answer key can be a practical reference for learners to check the truth of their answers. The key answers given are also only the result so that 
students are still required to solve their problemsolving steps. The key answers serve as a learner's guide to test answers, and feedback for teachers to find out how far the learners learn success level of the learning indicators. Test answers refer to the content of the lesson. Subjective answers should be short and compact and do not elicit another or different interpretation [20].

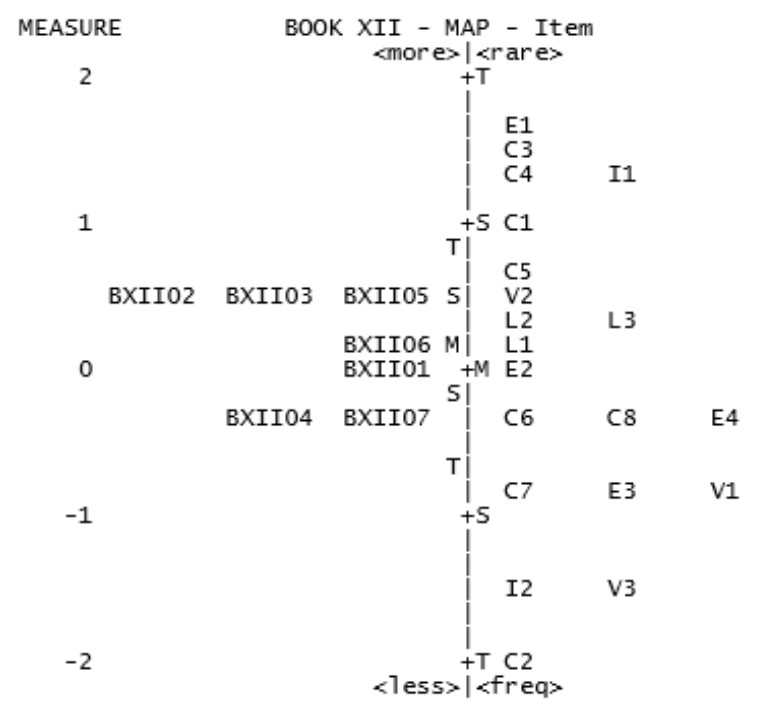

FIGURE 8. The result of Physics Book Analysis on Class XII

The analysis result of the completeness in the book based on Figure 8 shows that the complete book of class XII physics is BXII02, BXII03, and BXII05 while the less complete are books BXII04 and BXII07. The lack of completeness in the ESB class XII physics book is the same as the class X and XI classes, namely in the aspect of initial competence/pretest (E1), conformity with learning objectives (C3), systematic presentation of material in accordance with the curriculum 2013 (C4), and clarity of learning objectives (I1).

Assessment of physics book class X, XI, and XII, in general, is good enough, but need some recommendation of systematics of writing that consists of parts such as the existence of learning objectives, apperception and motivation in the form of events that occur in everyday life, key words , concept maps, discussion columns that require learners to associate previous concepts, material explanations in accordance with learning objectives, competence questions, scientist columns that require learners to demonstrate a concept, an activity that includes observation and literature review of the material being studied, figures displaying profiles of scientists, our info describing modern technological discoveries related to the material discussed, summaries in each chapter, training consisting of questions corresponding to learning objectives and teaching materials, semester training that includes questions from the collection material discussed on the seti ap semester, key answer questions, bibliography, table of contents, list of images and table lists, glossary, subject index and author, and attachments consisting of the values of constants used. ESBs should have a list of contents automatically to make it easier for readers to access the material. Electronic books should also be facilitated by access to other online reading resources to help learners understand the concept thoroughly [21].

\section{CONCLUSION}

Overall, it can be concluded that most available physics ESBs have been good but not by the systematics of material present in the 2013 curriculum and have not had a clear learning objective so that there is material nonconformity with the purpose of learning. Therefore, the ESB needs to be done to improve the systematic presentation to be applied in the 2013 curriculum.

\section{ACKNOWLEDGMENT}

The author expresses his gratitude to the Dean of the Fakultas Keguruan dan Ilmu Pendidikan Universitas Papua for his support and motivation so that this research can be carried out well.

\section{REFERENCES}

[1] Idrees, M., Habib, Z.andHafeez, M. A. (2014). "Evaluating and Comparing the Textbooks of General Science: A Comparative Study of Published Textbooks in Pakistan.' International J. Soc. Sci. \& Education4(2): 551-555.

[2] Ali, I., Akhter, N.and Nawaz, M. (2017). "Critical Analysis of General Science Textbooks for Inclusion of the Nature of Science Used At Elementary Level in Khyber Pakhtunkhwam."Journal of Educational Research 20(1): 113-131.

[3] Abdulaziz, M. F., Rahayu, T.andRahayu, S.(2014)."Analisis Isi (Content Analysis) BukuSekolahElektronik (BSE) PelajaranPendidikanJasmaniOlahragadanKesehatan SMP Kelas VIII di Kota Semarang."Journal of Physical Education and Sports 3(1): 1-5.

[4] Mahmood, K. (2011). "Conformity to Quality Characteristics of Textbooks: The Illusion of Textbook Evaluation in Pakistan."Journal of Research and Reflections in Education5(2): 170-190.

[5] Astuti, D. P., Siswandari, Santoso, D.(2017). "E-Book for Problem Based Learning to Improve Learning Outcome of the Students."Advances in Social Science, Education and Humanities Research (ASSEHR) 158(2017):220-227.

[6] Laketa, S. andDrakulić, D. (2015). "Quality of Lessons in Traditional and Electronic Textbooks."Interdisciplinary Description of Complex Systems 13(1): 117-127.

[7] Gray, D. J. and Copeland, A. J. (2012). "E-book versus Print A Per-Title Cost and Use Comparison of a Public Library's Popular Titles.”Reference \& User Services Quarterly51(4): 334-39.

[8] Lammer L., Edwars, J. and Rapule, S.(2008)."Educators' Selection and Evaluation of Natural Sciences Textbooks.South African Journal of Education28(2008): 175-187.

[9] Collette, A. T.andChiapetta, E. L.,Science Intoduction in The Middle and Secondary Schools(Macmillan, New York, 1994), pp.98-102.

[10] Mohan, R., Innovative Science Teaching-For Physical Science Teachers (PHI Learning Private Limited, Delhi, 2013), pp. 325-326. 
[11] David, A., Rasch Models for Measurement Sage University Papers Series, Quantitative Applications in the Social Sciences (Sage Publications, London, 1988), pp. 91-105.

[12] Waller, D. (2013). "Current Advantages and Disadvantages of Using E-Textbooks in Texas Higher Education.'Focus on Colleges, Universities, and Schools7(1): 1-6.

[13] Moody, A. K. (2010). "Using Electronic Books in the Classroom to Enhance Emergent Literacy Skills in Young Children."Journal of Literacy and Technology 11(4): 22-51.

[14] Ismail, R.andZainab, A. N. (2005). "The Pattern of Ebook Use Amongst Undergraduates in Malaysia: A Case of to Know is to Use."Malaysian Journal of Library \& Information Science10(2): 1-23.

[15] Yusuf, I. and Subaer(2013)."PengembanganPerangkatPembelajaranFi sikaberbasisMedia Laboratorium VirtualpadaMateriDualismeGelombangPartikel di SMA Tut WuriHandayani Makassar.”JurnalPendidikan IPA Indonesia2(2): 189-194.

[16] Yusuf, I.,Widyaningsih, S. W. and Purwati, D.(2015)."PengembanganPerangkatPembelajaranFisika Modern berbasisMedia Laboratorium Virtual
berdasarkanParadigmaPembelajaran Abad 21 danKurikulum2013.'PancaranPendidikan4(2): 189-200.

[17] Bancong, H. and S. Jinwoong (2018)."Do Physics Textbooks Present the Ideas of Thought Experiments?: A Case in Indonesia."JurnalPendidikan IPA Indonesia7(1): 25-33.

[18] Chasanah, U. U., Sinon, I. L. S.andWidyaningsih, S. W. (2016). "Penerapan Model KooperatifTipe STAD (Student Team Achivement Divisions) dengan Media Peta KonsepuntukMeningkatkanHasilBelajar IPA $\begin{array}{lllll}\text { PesertaDidikKelas IX A } & \text { SMP Negeri } 19\end{array}$ Manokwari.'PancaranPendidikan5(2): 25-38.

[19] Aydin, G. (2013). "The Effects of TechnologySupported Mind and Concept Mapping on Students' Construction of Science Concepts The Effect of Mind Mapping in Science Education."Anthropologist20(1,2): 166-176.

[20] Lestari, A. S. (2014). "PembuatanBahan Ajar BerbasisModulpadaMatakuliah Media Pembelajaran di JurusanTarbiyah STAIN Sultan QaimuddinKendari.”Jurnal Al-Ta'dib7(2): 154-176.

[21] Ebied, M. M. A. andRahman, S. A. A. (2015). "The Effect of Interactive E-book on Students' Achievement atNajran University in Computer in Education Course."Journal of Education and Practice6(19): 71-82. 